\title{
Dynamics of natural infection by Toxoplasma gondii in goat herds in the semiarid region of northeastern Brazil
}

\author{
Larissa Nascimento Sousa \\ UFCG: Universidade Federal de Campina Grande \\ Samira Pereira Batista \\ UFCG: Universidade Federal de Campina Grande \\ Samara Santos Silva \\ UFCG: Universidade Federal de Campina Grande \\ Rômulo Fylipe Silva \\ IFPB: Instituto Federal de Educacao Ciencia e Tecnologia da Paraiba \\ Wlysse Ferreira Sarmento \\ IFPB: Instituto Federal de Educacao Ciencia e Tecnologia da Paraiba \\ Rinaldo Aparecido Mota \\ UFRPE: Universidade Federal Rural de Pernambuco \\ Arthur Willian Lima Brasil \\ UFPB: Universidade Federal da Paraiba \\ Marcos Amaku \\ USP: Universidade de Sao Paulo \\ Thais Ferreira Feitosa \\ IFPB: Instituto Federal de Educacao Ciencia e Tecnologia da Paraiba \\ Vinícius Longo Ribeiro Vilela ( $\nabla$ vilelavlr@yahoo.com.br) \\ Instituto Federal da Paraíba https://orcid.org/0000-0001-9891-7842
}

\section{Research Article}

Keywords: abortion, goat farming, epidemiology, longitudinal, toxoplasmosis

Posted Date: August 23rd, 2021

DOl: https://doi.org/10.21203/rs.3.rs-815073/v1

License: () (7) This work is licensed under a Creative Commons Attribution 4.0 International License. Read Full License 


\section{Abstract}

This study aimed to describe the transmission of $T$. gondii in naturally infected goats in the semiarid region of northeastern Brazil, through evaluating the serological status of these animals from one to 12 months of age. Seven goat farms were selected. During the first visit, an epidemiological questionnaire was applied. Blood samples were collected from pregnant goats and from their female offspring every month, to monitor them for anti-T. gondii antibodies, using the indirect fluorescence antibody test (IFAT). Out of 66 pregnant goats evaluated, 47\% (31/66) (95\% Cl: 34.6\% - 59.7\%) were positive and out of 93 female offspring, 61.3\% (57/93) (95\% Cl: $52.4 \%-69.2 \%)$ were positive, in at least one month during the evaluation period. Among the positive female offspring, 43.3\% (27/57) (95\% Cl: $39.7 \%-56.9 \%)$ presented environmental infection and 56.7\% (30/57) (95\% Cl: $43.4 \%-66.3 \%)$ probably had only colostral antibodies or vertical transmission. It was observed that 92,6\% (25/27) from environmental infections occurred until reproductive age (six months) $(p<0.0001)$. It was also noted that there is a correlation between the titration of mothers and offspring, until four months of age $(p<0.0001)$. Large fluctuations in the presence of antibodies were observed among the animals over the months monitored. It can be concluded that the prevalence of anti-T. gondii antibodies within the herds was greater than what has been expressed in specific prevalence studies and that most sheep become infected up to the six months of life in the studied area.

\section{Introduction}

Raising goats for meat, leather and milk production is an important global economic activity (Dubey 2020). Thus, diseases that cause reproductive problems in goats generate significant economic losses for producers and have a negative impact on productivity (Pinheiro et al. 2000). In this way, the diseases that traditionally form part of health management for goat herds join together with emerging diseases, among which toxoplasmosis stands out, mainly due to the reproductive disorders that it can cause (Lucio et al. 2016).

Toxoplasma gondii, a protozoon that forms tissue cysts, is considered to be one of the main causes of reproductive disease in goats and gives rise to large economic losses (Dubey 2021). Reproductive failure is one of the important clinical consequences of primary $T$. gondii infection acquired during pregnance. The main problems observed comprise embryo resorption, fetal death, mummification, abortion and birth of weakened offspring (Blewett 1983; Buxton 1998; Dubey 2021; Wanderley at al. 2013).

Transmission of $T$. gondii can occur through ingestion of sporulated oocysts present in contaminated water or food; through ingestion of tissue cysts present in the muscles of the definitive host; or transplacentally. The latter is a possible route for transmission to goats when the mother is infected during the gestational period (Dubey 2021). According to Dubey et al. (2020), reproductive losses in goats are much more serious than in sheep. In addition, goats can transmit toxoplasmosis to humans (Orlando et al. 2017), such that this disease can become a global anthropozoonosis, with great importance with regard to public health, due to the high risk that the disease poses for immunocompromised people (Belluco et al. 2016; Wang et al. 2017; Dubey et al. 2020).

In goats, the diseases can be silent (Belluco et al. 2016) but the prevalence of antibodies anti-T. gondii can be very high. According to Dong (2018), the following prevalences of anti-T. gondii antibodies have been found in goats around the world: $19.4 \%$ (393/2026) in North America; 35.9\% (2878/8027) in Africa; 30.1\% (2107/6988) in Europe; 25.2\% (75/298) in Oceania; and 21.3\% (1346/6311) in Asia. In Brazil, however, high variability in prevalence rates has been observed, ranging from 3.47-81.8\% (Costa et al. 2012; Medeiros et al. 2014; Santos et al. 2018).

Occurrences of T. gondii infection in aborted goat fetuses have been reported in several countries around the world (Charleston 1994; Navarro et al. 2009; Caldeira et al. 2011; Albu-Dalbouch et al. 2012; Unzaga et al. 2014). In a retrospective study on goat abortions in California, USA, 211 cases that occurred between 1991 and 1998 were analyzed, and the result showed that only $4 \%$ of these were of protozoan origin (Moeller 2001). In the state of Paraná, Brazil, in a study on 179 goats, among which 33 had had abortions, 137 (76.53\%) were serologically positive and 11 (33\%) of the 33 goats with symptoms were positive in PCR (Ferreira Neto et al. 2018). Mesquita et al. (2019) reported on an outbreak that occurred in Alagoas in 80 animals, in which, among 27 placenta samples analyzed, $23(85.2 \%)$ were positive in immunohistochemical tests.

In Brazil, it is likely that many cases of toxoplasmosis in goats go unreported (and thus that the number of cases is underreported), due to the scarcity of studies aimed at diagnosing the causes of abortion and the absence of a standard for analyses on placental and fetal tissues (Mesquita et al. 2019). Some authors have even emphasized that outbreaks may be really scarce, as shown in the 
literature (Moeller 2001). There is no information on the age group most prone to primary infection among goats, or whether most animals become infected before entering reproductive age and would thus have some level of immunity against $T$. gondii infection.

Thus, the aim of the present study was to investigate the dynamics of anti-T. gondii antibodies in female goats aged one to 12 months, through evaluating the serological conditions of these animals and ascertaining the time at which the primary infection occurred.

\section{Material And Methods}

\subsection{Study location}

This study was carried out between December 2018 and April 2020, in the Sertão region of the state of Paraíba, northeastern Brazil. This is a semi-arid tropical area that is characterized by hot and dry landscapes. It has an average temperature of $26.6^{\circ} \mathrm{C}$, with low annual thermal variability (INMET 2010). Rainfall is irregular, but two annual climatic periods are distinctly marked out: rainy, between the months of January and May, with a maximum of $700 \mathrm{~mm}$ to $900 \mathrm{~mm}$; and dry, between the months of June and December, marked by long periods of drought, with a mean of around $10 \mathrm{~mm}$ (Francisco and Santos 2017).

The herds in the region studied region are subjected to a semi-intensive rearing regime. They graze during the day in areas of native vegetation of the Caatinga biome, mainly composed of mata-pasto (Senna obtusifolia L.), jurema-preta (Mimosa tenuiflora), catingueira (Caesalpinia pyramidalis), quince (Croton sonderianus), Malva (Malva sp.), juazeiro (Zizyphus joazeiro), sabiá (Mimosa caesalpiniifolia) and favela (Cnidoscolus phyllacanthus).

\subsection{Experimental design and management of herds}

Seven goat farms were selected, located in the municipalities of Pombal (P1), Nazarezinho (P2), Aparecida (P3 and P4), Marizópolis (P5) and Pedra Branca (P6 and P7) (Fig. 1). All the farms selected had at least 50 animals and included between three and 20 female goats that were in the final stage of pregnancy, in order to perform serological tests for $T$. gondii.

During the first visit to these farms, an epidemiological questionnaire was applied to the owner. This sought information relating to the physical structure of the farm, productive characteristics of the herd, purpose of rearing, type of food management, use of mineral supplementation, health care performed and its frequency and data on reproductive control, including crossbreeding, births and mortality. In addition, the presence of pre-existing diseases in the herd was investigated. In particular, it was ought to determine whether these were reproductive diseases.

\subsection{Animals and sample collection}

The female goats underwent abdominal palpation examination (Ishwar 1995), to identify final-stage pregnancy. Blood samples were collected for screening. Female offspring born from these goats were also identified and their anti-T. gondii antibodies levels were monitored monthly until 12 months of age. Pre-ingestion colostrum was not collected, but all the goat kids underwent their first blood collection before reaching one month of life (Valencio et al. 2020).

Blood samples were collected by puncturing the external jugular vein, using $5 \mathrm{ml}$ disposable syringes. Subsequently, they were chilled and were sent to the Laboratory of Immunology and Infectious Diseases (LIDIC) of the Federal Institute of Paraíba (IFPB), Campus Sousa, Paraíba, for serum to be obtained. These serum samples were then stored at $-20^{\circ} \mathrm{C}$, until the time when the analyses were performed.

\subsection{Diagnosing of anti-T. gondii antibodies}

To diagnose the presence of anti-T. gondii antibodies in goats, the indirect fluorescence antibody test (IFAT) was performed, using the cutoff titer of 1:64 (GARCIA et al. 1999). Serum dilution was performed in a 96-well microplate, using $3 \mu \mathrm{L}$ of the serum to be tested and $189 \mu \mathrm{L}$ of phosphate-buffered saline (PBS) solution ( $\mathrm{pH} \mathrm{7.2).} \mathrm{After} \mathrm{dilution,} 20 \mu \mathrm{L}$ were placed on a slide previously fixed with tachyzoites. This was then incubated in an oven $\left(37^{\circ} \mathrm{C}\right.$ for 30 minutes). After incubation, the slides were subjected to three washes by means of immersion in PBS, with 10 minutes for each wash. After drying, each slide was covered with $20 \mu \mathrm{L}$ of goat anti-IgG conjugate (whole molecule, SIGMA, St. Louis, MO, USA). The material was incubated for another 30 minutes at $37^{\circ} \mathrm{C}$ in an oven. After the three washes and drying, the slides were evaluated by means of fluorescence microscopy with ultraviolet light emission. Serum samples that reacted at dilutions greater than or equal to 1:64 were considered positive, and these positive samples were then subjected to sequential dilutions at base two until negative.

Page $3 / 12$ 


\subsection{Data analysis}

To evaluate a possible correlation between antibody titers from mothers $\mathrm{x}$ offspring, Spearman's $(\rho)$ correlation test was applied. To compare the proportion of offspring which seroconverted up to the 6th month of age with which seroconverted after the 6th month of age, a Mcnemar test for paired samples was used and, for this analysis, positive offspring in the first month of age were excluded.

To identify the factors associated with occurrences of $T$. gondii, the chi-square test was performed to select the variables that presented a statistically significant difference ( $p \leq 0.2)$ (Zar 1999). These variables were subjected to multivariate analysis, in which a multiple logistic regression test was used, with a significance level of $5 \%$ (Hosmer and Lemeshow 2000). Calculations were made using the Minitab 19 software (Minitab Inc. 2020).

\section{Results}

The seven farms evaluated had goats that were positive for anti-T. gondii antibodies during the experimental period. In total, 66 matrices goats were evaluated, of which $47 \%$ (31/66) (95\% Cl: $34.6 \%-59.7 \%)$ were positive; and their 93 female offspring, among which $61,3 \%$ (57/93) (95\% Cl: 52.4\% - 69.2\%) were positive at some point during the evaluation period.

The titers presented by the positive matrices goats in the IFAT ranged from 1:64 to 1:1024. Among the 57 offspring, that were positive at some point during the experimental period, the titers ranged from 64 to 2048 over the study period, as described in Table 1. In the first month of life, it was observed that 52,6\% (30/57) (95\% Cl: $39.4 \%-59.3 \%)$ of the offspring showed anti-T. gondii antibodies. It was found that $93,5 \%$ (29/31) (95\% Cl: $74.3 \%-97.3 \%)$ of the offspring that were seropositive in the first month of life were born from positive mothers. Tthe mother's title has correlation with titration of offspring until four months of age (Fig. 2). 
Table 1

Titers among female offspring that were positive for anti-T. gondii antibodies in the indirect fluorescence antibody test (IFAT), according to age in months, during the experimental period, on seven goat farms in the semiarid region of northeastern Brazil.

\begin{tabular}{|c|c|c|c|c|c|c|c|c|c|c|c|c|c|c|}
\hline \multirow[t]{2}{*}{ Farms } & \multirow{2}{*}{$\begin{array}{l}\text { Antibody } \\
\text { titer for } \\
\text { mother }\end{array}$} & \multirow{2}{*}{$\begin{array}{l}\text { Identification } \\
\text { of offspring }\end{array}$} & \multicolumn{12}{|c|}{ Months of age } \\
\hline & & & 1 & 2 & 3 & 4 & 5 & 6 & 7 & 8 & 9 & 10 & 11 & 12 \\
\hline P1 & 256 & $102 \mathrm{~F} 1$ & 64 & 256 & 64 & 0 & 0 & 0 & 0 & 0 & 0 & 0 & 0 & 0 \\
\hline P1 & $<64$ & $122 \mathrm{~F} 1$ & 0 & 0 & 0 & 0 & 0 & 0 & 0 & 0 & 512 & 512 & 128 & NC \\
\hline P2 & 512 & 202F1 & 512 & 512 & 256 & 256 & 1024 & 512 & 256 & 0 & 0 & NC & NC & NC \\
\hline P2 & $<64$ & 206F1 & 0 & 0 & 0 & 0 & 0 & 0 & 0 & 128 & 64 & 0 & NC & NC \\
\hline P2 & $256^{\star \star}$ & $207 F 2$ ** & 512 & 512 & 0 & 1024 & 512 & 512 & 128 & 64 & 64 & 0 & 0 & 0 \\
\hline P2 & 256 & 208F1 & 64 & 64 & 0 & 0 & 64 & 128 & 0 & 0 & 0 & 0 & 0 & NC \\
\hline P2 & $<64$ & $209 F 2$ & 0 & 0 & 0 & 0 & 0 & 64 & 0 & 0 & 0 & 0 & 0 & 0 \\
\hline P2 & 512 & 210F1 & 1024 & 1024 & 128 & 64 & 0 & 0 & 0 & 0 & 128 & 64 & 0 & 0 \\
\hline P2 & 1024 & $211 \mathrm{~F} 1$ & 1024 & 2048 & 512 & 128 & 64 & 64 & 512 & 128 & 128 & NC & NC & NC \\
\hline P3 & $<64$ & $304 \mathrm{~F} 1$ & 0 & 0 & 0 & 0 & 0 & 64 & 0 & 0 & 0 & 0 & 0 & 0 \\
\hline P3 & 64 & $305 F 1$ & 0 & 0 & 256 & 128 & 128 & 128 & 64 & 64 & 64 & 0 & 0 & 0 \\
\hline P3 & $<64^{\star \star}$ & $601 F 2^{\star \star}$ & 0 & 0 & 512 & 256 & 64 & 64 & 64 & 0 & 0 & 0 & 0 & 0 \\
\hline P3 & $<64$ & $602 \mathrm{~F} 1$ & 0 & 0 & 0 & 0 & 64 & 64 & 64 & 64 & 0 & 0 & 0 & 128 \\
\hline P3 & $<64^{\star \star}$ & $603 F 1 * \star$ & 0 & 0 & 512 & 512 & 256 & 128 & 64 & 0 & 0 & 0 & 0 & 0 \\
\hline P3 & $<64$ & 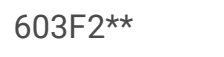 & 0 & 0 & 0 & 0 & 64 & 0 & 0 & 0 & 0 & 0 & 0 & 0 \\
\hline P3 & $<64$ & 604F1 & 0 & 0 & 0 & 64 & 0 & 0 & 0 & 0 & 0 & 0 & 0 & NC \\
\hline P3 & $64^{\star \star \star}$ & 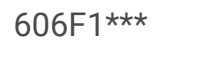 & 0 & 0 & 0 & 512 & 512 & 128 & 0 & 0 & 0 & 0 & 0 & 0 \\
\hline P3 & 64 & 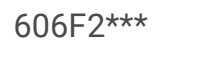 & 0 & 0 & 0 & 64 & 64 & 128 & 64 & 0 & 0 & 0 & 0 & 0 \\
\hline P3 & 512 & $26 \mathrm{~F} 1$ & 256 & 256 & 128 & 64 & 64 & 0 & 0 & 0 & 0 & 0 & 0 & 0 \\
\hline P3 & 512 & 77F2 & 1024 & 1024 & 1024 & 512 & 64 & 64 & 0 & 0 & 0 & 0 & 0 & 0 \\
\hline P3 & 512 & $78 \mathrm{~F} 1$ & 2048 & 1024 & 256 & 64 & 0 & 0 & 0 & 0 & 0 & 0 & 0 & 0 \\
\hline P4 & $<64$ & $850 F 1$ & 0 & 128 & 256 & 0 & 0 & 0 & 0 & 0 & 0 & 0 & 0 & 0 \\
\hline P4 & $<64$ & $851 \mathrm{~F} 1$ & 0 & 0 & 0 & 64 & 0 & 0 & 0 & 0 & 0 & 0 & 0 & 0 \\
\hline P4 & 64 & $852 \mathrm{~F} 1$ & 0 & 0 & 256 & 256 & 256 & 256 & 64 & 0 & 0 & 0 & 0 & 0 \\
\hline P5 & 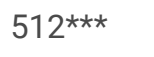 & $24 \mathrm{~F} 3 * \star \star$ & 1024 & 1024 & 512 & 128 & 64 & 1024 & 512 & 128 & 64 & 64 & 64 & 0 \\
\hline P5 & $64 * \star$ & $32 \mathrm{~F} 2 * \star$ & 512 & 512 & 128 & 128 & 64 & 64 & 0 & 0 & 0 & 0 & 0 & 0 \\
\hline P5 & $512^{\star \star}$ & $30 \mathrm{~F} 1$ ** & 512 & 128 & 128 & 128 & 64 & 64 & 0 & 0 & 0 & 0 & 0 & 0 \\
\hline P6 & $<64$ & $250 \mathrm{~F} 1$ & 64 & 0 & 0 & 0 & 0 & 0 & 0 & 0 & 0 & 0 & NC & NC \\
\hline P6 & $64^{\star *}$ & $012 F 1^{\star \star *}$ & 64 & 0 & 0 & 0 & 1024 & 512 & 128 & 128 & 64 & 0 & 0 & 0 \\
\hline P6 & 64 & $012 \mathrm{~F} 2^{\star \star}$ & 512 & 128 & 64 & 64 & 0 & 0 & 0 & 0 & 0 & 0 & 0 & 0 \\
\hline P6 & $<64$ & 07F1 & 512 & 128 & 128 & 64 & 64 & 0 & 0 & 0 & 0 & 0 & 0 & 0 \\
\hline P6 & 1024 *夫 & 10F1** & 512 & 64 & 64 & 0 & 0 & 0 & 0 & 0 & 0 & 0 & 0 & 0 \\
\hline
\end{tabular}




\begin{tabular}{|c|c|c|c|c|c|c|c|c|c|c|c|c|c|c|}
\hline \multirow[t]{2}{*}{ Farms } & \multirow{2}{*}{$\begin{array}{l}\text { Antibody } \\
\text { titer for } \\
\text { mother }\end{array}$} & \multirow{2}{*}{$\begin{array}{l}\text { Identification } \\
\text { of offspring }\end{array}$} & \multicolumn{12}{|c|}{ Months of age } \\
\hline & & & 1 & 2 & 3 & 4 & 5 & 6 & 7 & 8 & 9 & 10 & 11 & 12 \\
\hline P6 & 1024 & $10 \mathrm{~F} 2^{\star \star}$ & 1024 & 512 & 256 & 128 & 128 & 64 & 64 & 0 & 0 & 0 & 0 & 0 \\
\hline P6 & 512 & 09F1** & 0 & 64 & 0 & 0 & 0 & 0 & 0 & 0 & 0 & 0 & 0 & 0 \\
\hline P6 & $512^{\star \star}$ & $09 \mathrm{~F} 2$ ** & 64 & 64 & 64 & 64 & 0 & 0 & 0 & 0 & 0 & $\mathrm{NC}$ & NC & $\mathrm{NC}$ \\
\hline P6 & $1024^{\star \star}$ & $43 F 1$ ** & 64 & 64 & 64 & 0 & 0 & 0 & 0 & 0 & 0 & 0 & NC & $\mathrm{NC}$ \\
\hline P6 & 1024 & $43 F 2$ *夫 & 1024 & 512 & 512 & 128 & 64 & 0 & 0 & 0 & 0 & 0 & $\mathrm{NC}$ & $\mathrm{NC}$ \\
\hline P6 & $<64^{\star \star}$ & $44 \mathrm{~F} 1^{\star \star}$ & 0 & 0 & 0 & 0 & 0 & 128 & 128 & 64 & 64 & 0 & 0 & 0 \\
\hline P6 & $<64$ & $44 \mathrm{~F} 2$ ** & 0 & 0 & 0 & 64 & 64 & 0 & 256 & 64 & 64 & 0 & 0 & 0 \\
\hline P6 & 512 & $46 \mathrm{~F} 1$ & 1024 & 1024 & 1024 & 512 & 256 & 256 & 128 & 128 & 0 & 0 & 0 & $\mathrm{NC}$ \\
\hline P7 & 128 & $59 \mathrm{~F} 1$ & 64 & 64 & 64 & 0 & 0 & 0 & 0 & 0 & 0 & 0 & 0 & 0 \\
\hline P7 & 512 & $45 \mathrm{~F} 1$ & 128 & 128 & 64 & 0 & 0 & 0 & 0 & 0 & 0 & 0 & 0 & 0 \\
\hline P7 & 128 & $48 \mathrm{~F} 1$ & 128 & 64 & 64 & 0 & 0 & 0 & 0 & 0 & 0 & 0 & 0 & 0 \\
\hline P7 & $<64$ & $57 F 1$ & 0 & 0 & 0 & 0 & 0 & 64 & 64 & 64 & NC & $\mathrm{NC}$ & $\mathrm{NC}$ & $\mathrm{NC}$ \\
\hline P7 & $<64$ & 50F1 & 0 & 128 & 128 & 64 & 64 & 0 & 0 & 0 & 0 & NC & NC & $\mathrm{NC}$ \\
\hline P7 & 512 & $38 \mathrm{~F} 1$ & 128 & 128 & 64 & 64 & 0 & 0 & 0 & 0 & 0 & 0 & 0 & $\mathrm{NC}$ \\
\hline P7 & $<64^{\star \star}$ & $03 \mathrm{~F} 2$ ** & 0 & 0 & 128 & 64 & 0 & 0 & 0 & 0 & 0 & 0 & 0 & 0 \\
\hline P7 & $<64$ & $280 \mathrm{~F} 1$ & 0 & 0 & 0 & 0 & 0 & 128 & 128 & 64 & 64 & 0 & 0 & 0 \\
\hline P7 & $<64^{\star \star}$ & $018 \mathrm{~F} 1^{\star \star}$ & 256 & 0 & 0 & 0 & 0 & 0 & 0 & 0 & 0 & 0 & 0 & 0 \\
\hline P7 & $<64$ & 11GAF1 & 0 & 0 & 512 & 256 & 256 & 256 & 128 & 64 & 64 & 64 & 64 & 0 \\
\hline P7 & 512 & 16F1 & 1024 & 256 & 128 & 64 & 64 & 64 & 64 & 64 & NC & NC & $\mathrm{NC}$ & $\mathrm{NC}$ \\
\hline P7 & 64 & 17F1 & 0 & 0 & 0 & 0 & 0 & 0 & 1024 & 512 & 128 & 128 & 128 & 128 \\
\hline P7 & $<64$ & 056F1 & 0 & 0 & 0 & 0 & 0 & 128 & 0 & 0 & 0 & 0 & 0 & 0 \\
\hline P7 & $<64$ & 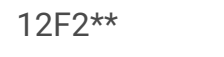 & 0 & 0 & 0 & 0 & 0 & 128 & 64 & 64 & 64 & 0 & 0 & 0 \\
\hline P7 & 64 & 19F1 & 128 & 128 & 64 & 0 & 0 & 0 & 512 & 512 & 0 & 0 & 0 & 0 \\
\hline P7 & 512 & $41 \mathrm{~F} 1$ & 64 & 64 & 64 & 0 & 0 & 0 & 0 & 0 & 0 & 0 & 0 & 0 \\
\hline P7 & $64^{\star \star}$ & $01 \mathrm{~F} 1^{\star *}$ & 64 & 64 & 0 & 0 & 0 & 0 & 0 & 0 & 0 & 0 & 0 & 0 \\
\hline
\end{tabular}

It was found that $47,3 \%(27 / 57)(95 \% \mathrm{Cl}: 39.7 \%-56.9 \%)$ of the offspring became infected through horizontal transmission, excluding all positive animals in the first month, as it is not possible to assess with certainty whether the antibody is colostral or from a transplacental infection. About the period of infection, it was determined that most infections occurred up to six months of age $(p<$ 0.00001).

During the experimental period, there was variation in the positivity of the goats, such that positive animals remained positive for short periods. In many cases, the same animal was positive and then negative during the first year of life (Table 1). It was seen that $68.4 \%$ (39/57) (95\% Cl: $53.3 \%-79.3 \%)$ of the animals evaluated had detectable antibody titers for only up to four consecutive months, and then they became negative. In addition, $73 \%(14 / 19)(95 \% \mathrm{Cl}: 48.8 \%-90.9 \%)$ of the animals that had antibodies for more than four consecutive months were positive from the first month of life onwards.

Among the mothers that were positive during pregnancy, 35.5\% (11/31) (95\% Cl: $19.2 \%-54.6 \%)$ had twin births and $6.5 \%(2 / 31)(95 \%$ $\mathrm{Cl}: 0.79 \%-21.4 \%)$ had triple births. It was observed that even among the positive mothers that had double and triple births, at least 
one of their offspring was negative in the first month of life. Out of the 22 goats born from twin births, $31,8 \%$ were negative in the first month. Out of the six kids that were born from triple deliveries, only one (15.1\%) had anti-T. gondii antibodies in the first month, and this animal (24F3) remained positive throughout the experimental period.

Regarding management, it was observed that the animals did not receive vaccination. Wild animals were present on all the farms, and on $42.8 \%(3 / 7)$ domestic cats that were in direct contact either with the herd or with the pasture were present. On four farms (P1, P2, P6 and P7), the animals received supplementation with corn-soy protein-energy concentrate ( $0.5 \%$ of live weight), in the late afternoons. The other farms (P3, P4 and P5) did not receive any protein-energy supplementation. Management practices such as navel disinfection, quarantining of newly acquired animals, proper disposal of carcasses and a place for an infirmary were not practiced on any of the farms evaluated. All the herds had the purpose of subsistence, without veterinary assistance, and the animals were being reared for their meat. Goat herding was the main activity of these farms

Comparison performed using multiple logistic regression, of infected animals on the farms between the categories of the variables analyzed (presence of cats, type of water supplied, type of enclosure, sanitary management and presence of sewage on the farm) showed that there were no statistically significant differences regarding these variables $(p>0.05)$.

\section{Discussion}

A total of 93 female offspring were serologically monitored, among which $61.3 \%$ had anti-T. gondii antibodies in at least one evaluation. During the experimental period, there were constant variations in antibodies among the female offspring, with animals showing different and variable periods of positivity and negativity for anti-T. gondii antibodies. Thus, some animals seroconverted before reaching six months of life and others only after six months of life. These differences in antibody behavior show the importance of periodic monitoring of these animals. In comparing the numbers of positive animals found in the present study, we observed that they were higher than those described in punctual studies carried out in northeastern Brazil (Garcia et al. 2012; Lucio et al. 2016). This result shows that punctual studies do not represent the real occurrence of anti-T. gondii antibodies in herds.

The sixth month of age was defined as the milestone for reproductive age, based on Fonseca (2011), who described the reproductive age of goats in northeastern Brazil. Among the offspring analyzed, 59.1\% (55/93) had antibodies with titers ranging from 64 to 1024 until 6th month of age. Thus, they reached reproductive age with active immunity against $T$. gondii. This would reduce the risk of acquiring toxoplasmosis in the acute phase, a factor that could lead to reproductive problems such as congenital transmission, with the possibility of embryonic absorption, abortions or stillbirths caused by T. gondii in these future mothers (Nunes et al. 2013).

Note that the titles obtained from offspring up to four months of age have a direct correlation with the titration found in their mothers, probably due to passive colostral antibody. This idea is reinforced by the findings from a study by Dubey et al. (1987), among lambs: they found evidence that passive immunity to $T$. gondii remains present and regresses until the third or fourth month postpartum. The three offspring that had anti-T. gondii antibodies in the first months of their lives and were born from negative mothers, may have become infected in the environment, through ingestion of water and food contaminated with oocysts. It can be too suggested that the presence of antibodies in these offspring was due to goat kids' behavior of not feeding exclusively from their own progenitors. This gives rise to the possibility that goat kids can ingest colostrum from positive mothers and thus become positive for passive immunity.

One offspring in the present study (\# 211F1) had high titers, reaching 2048 in the second month and remaining positive until the ninth month of life. Considering that this animal's mother was positive with a titer of 1024 , we can suggest that passive immunity was initially present and that environmental infection maintained this animal's positivity later on. Although no evaluation was done before ingestion of colostrum, we cannot rule out the possibility that transplacental transmission may have occurred in relation to this animal. Likewise, this may have occurred in relation to all the offspring that were evaluated as positive in their first month of life and presented persistence of antibodies.

In the cases of double and triple births from positive mothers, it was observed that at least one offspring was negative in the first month of life, and that the positive animals from the same goat had titers that differed from each other. Regarding these results, it can be suggested that competition for colostrum may have led to failure of passive immunity transfer (FPIT) between kids from multiple births. It has been report that the probability of FPIT among twins is greater than in single deliveries (McGuire et al. 1983; Christley et al. 2003; Tizard 2019). In addition, these data corroborate the findings of Gilbert et al. (1988), who demonstrated that the concentration of 
IgG decreases linearly with increasing numbers of lambs born from the same mother, which indicates that natural competition between twins, and fiercer competition among triplets, may be an important factor in relation to FPIT.

Among all the offspring monitored, 38,7\% (36/93) did not show anti-T. gondii antibodies at any time during the evaluation period and remained susceptible to infection throughout the experimental period. Considering the high environmental contamination of the region studied (Valêncio et al. 2020), these females are more susceptible to infection during the reproductive period, which considerably increases the risk of reproductive problems such as abortion, fetal malformation and stillbirths (Dubey 2021; Wanderley et al. 2013).

Regarding the form of rearing, all the herds evaluated here carried out semi-intensive rearing. This may explain the high prevalence of seroreactive animals. In a study by Djokic et al. (2014), rearing regimes that included grazing in fields imposed greater risk, since the animals could have access to contaminated pastures. In addition, the inadequate management of the herds that was practiced on the farms evaluated here can be considered to be an important factor in the animals' state of infection, given the scarcity of use of appropriate techniques for cleaning and sanitizing the environment, in the way suggested by Pereira et al. (2012) and Bawm et al (2016)

\section{Conclusion}

It was concluded that the level of positivity to anti-T. gondii antibodies in goats from the semiarid region of northeastern Brazil was high, the most goats become infected within the first six months of life in the studied area and that mother titles influence offspring titles up to four months of age. In addition, anti-T. gondii antibodies behave in a fluctuating manner, such that they persist in the animal's organism for a period of around three to four months. This demonstrates the importance of serological monitoring studies on goat herds, in order to better understand the epidemiology of $T$. gondii infections in goats.

\section{Declarations}

\section{Acknowledgements}

The authors would like to thank FAPESQ (Foundation for Research Support of the State of Paraíba) for the scholarship granted to LNS.

\section{Authors' contributions}

LNS, VLRV and TFF designed the experiments; LNS, SPB, SSS, RFS, WFS and RAM performed the experiments; LNS, VLRV, TFF and MA analyzed the data; LNS, VLRV and TFF wrote and edited the manuscript.

\section{Funding}

This study received no funding.

\section{Data availability}

All data generated or analyzed during this study are included in this published article.

\section{Declaration of Competing Interest}

The authors declare that they have no known competing financial interests or personal relationships that could have appeared to influence the work reported in this paper.

\section{Ethical statement}

The experiments conducted in this study were approved and performed according to the recommendations of the Ethics Committee on the Use of Animals of the Federal Institute of Paraíba, Campus Sousa (CEUA - IFPB), under protocol protocol 23000.001402.2018-64.

\section{Consent to participate}

Authors have permission to participate. 
Authors have permission for publication.

\section{References}

1. Abu-Dalbouh MA, Ababneh MM, Giadinis ND, Lafi S (2012) Ovine and caprine toxoplasmosis (Toxoplasma gondii) in aborted animals in Jordanian goat and sheep flocks. Trop Anim Health Prod 44:49-54

2. Bawm SB, Maung WY, Win MY, Thu MJ, Chel HM, Khaing TA, Wai SS, Htun LL, Myaing TT, Tiwananthagorn S, Igarashi M, Katakura K (2016) Serological Survey and factors associated with Toxoplasma gondii infections in domestic goat in Myanmar. Scientifica 2016: 1-4

3. Belluco S, Mancin M, Conficoni D, Simonato G, Pietrobelli M, Ricci A (2016) Investigating the Determinants of Toxoplasma gondii Prevalence in Meat: A Systematic Review and Meta-Regression. PLoS ONE 11(4):e0153856. https://doi.org/10.1371/journal.pone.0153856

4. Blewett DA (1983) The epidemiology of ovine toxoplasmosis. I The interpretation of data for the prevalence of antibody im sheep and other host species. Brit Vet J 139:537-545

5. Buxton D (1998) Protozoan infections (Toxoplasma gondii, Neospora caninum and Sarcocystis spp.) in sheep and goats: recent advances. BMC Vet Res 29 (3-4): 289-310

6. Caldeira FHB, Ubiali DG, Godoy I, Dutra D.Aguiar, DM., Melo ALT, Riet-Correa F, Colodel EM., Pescador CA. (2011) Outbreak of caprine abortion by Toxoplasma gondii in Midwest Brazil. Pesq Vet Bras 31 (11): 933-937

7. Charleston WAG (1994) Toxoplasma and other protozoan infections of economic importance in New Zealand. N Z J Zool 21:6781

8. Christley RM, Morgan KL, Parkin TDH, French NP (2003) Factors related to the risk of neonatal mortality, birth-weight and serum immunoglobulin concentration in lambs un the UK. Prev Vet Med 57(4):209-226

9. Costa DGC, Marvulo MFV, Silva JSA, Santana SC, Magalhães FJR, Lima Filho CDF, Ribeiro VO, Alves LC, Mota RA, Dubey JP, Silva JCR (2012) Seroprevalence of Toxoplasma gondii in domestic and wild animals from the Fernando de Noronha, Brazil. J Parasitol 98:679-680

10. Djoki'c V, Klun I, Musella V, Rinaldi L, Cringoli G, Sotiraki S, Djurkovic-Djakovic O (2014) Spatial epidemiology of Toxoplasma gondii infections in goats in Serbia. Geospat Health 8(2):479-488

11. Dong H, Su R, Lu Y, Wang M, Liu J, Jian F, Yang Y (2018) Prevalence, risk factors, and genotypes of Toxoplasma gondii in food animals and humans (2000-2017) from China. Front Microbiol 9:2108

12. Dubey JP (2021) Diagnosis. In: Toxoplasmosis of animals and humans, 1.7, $3^{\circ}$. CRC Press, ed. Boca Raton, pp 52-71

13. Dubey JP, Murata FHA, Cerqueira-Cézar CK, Kwok OCH (2020) Public health and economic importance of Toxoplasma gondii infections in goats: The last decade. Res Vet Sci 132:292-307

14. Ferreira Neto JM, Ferreira FP, Miura AC, Almeida JC, Martins FDC, Souza M, Bronkhorst DE, Romanelli PR, Pasquali AKS, Santos HLEPL, Benitez AN, Caldart ET, Zanella LF, Freire RL, Navarro IT (2018) An outbreak of caprine toxoplasmosis - invetiation and case report. Ciênc Rural 48(5):1-5

15. Fonseca JF, Cruz RC, Pinto PHN, Facó O (2011) Manual of synchronization and estrus induction and ovulation in sheep and goats. Sobral-CE: Embrapa Goats Sheep 103:1-59

16. Francisco PRM, Santos D (2017) Climatology of the State of Paraíba. EDUFCG, Campina Grande

17. Garcia JL, Navarro IT, Ogawa L, Oliveira RC (1999) Seroepidemiology of toxoplasmosis in cats and dogs from rural properties in the municipality of Jaguapitã, state of Paraná, Brazil. Rural Sci 29(1):99-104

18. Garcia G, Sotomaior C, Nascimento AJ, Navarro IT, Soccol VT (2012) Toxoplasma gondii in goats from Curitiba, Paraná, Brazil: risks factors and epidemiology. Rev Bras Parasitol Vet 21(1):42-47

19. Gilbert RP, Gaskins CT, Hillers JK, Parker CF, Mcguire TC (1988) Genetic and environmental factores affecting immunoglobulin G1 concentrations in ewe colostrum and lamb serum. J An Sci 66(4):855-863

20. Hosmer DW, Lemeshow S (2000) Applied logistic regression. 2nd Edition, John Wiley \& Sons, Inc., New York. doi:10.1002/0471722146

21. Instituto Nacional de Meteorologia - INMET (2010) Normais climatológicas do Brasil 1981-2010.

http://www.inmet.gov.br/portal/index.php?r=clima/normaisClimatologicas Accessed 03 December 2020

Page $9 / 12$ 
22. Ishwar AK (1995) Pregnancy diagnosis in sheep and goats: a review. Small Rum Res 17:37-44

23. Lúcio EC, Clemente SMS, Pimentel JL, Oliveira JMB, Silva Júnior JL, Albuquerque PPF, Mota RA, Pinheiro Junior JW (2016) Epidemiological analysis of Toxoplasma gondii infection in goats in the state of Pernambuco, Brazil. Rev Bras Med Vet 38(1):1318

24. Mcguire TC, Regnier J, Kellom T, Gates N (1983) Failure in passive transfer of immunoglobulin G1 to lambs: measurement of immunoglobulin G1 in ewe colostrums. Am J Vet Res 44(6):1064-1067

25. Medeiros AD, Andrade MMC, Vitor RWA, Andrade-Neto VF (2014) Occurrence of anti-Toxoplasma gondii antibodies in meat and dairy goat herds in Rio Grande do Norte, Brazil. Rev Bras Parasitol Vet 23(4):481-487

26. Mesquita EP, Oliveira JMB, Silva GM, Torres SM, Oliveira AAF, Silva Júnior VA, Mota RA, Amorim MJAAL (2019) Immunodetection of Toxoplasma gondii in placental tissue of naturally infected goats. Arq Bras Med Vet Zootec 71:86-92

27. Moeller RB (2011) Causes of caprine abortion: diagnostic assessment of 211 cases (1991-1998). J Vet Diagn Invest 13:265-270

28. Navarro JA, Ortega N, Buendia AJ, Martínez CM, Sánchez J, Gallego MC, Caro MR, Salinas J (2009) Diagnosis of placental pathogens in small ruminants by immunohistochemistry and PCR on paraffin-embedded samples. Vet Rec 165:175-178

29. Nunes FVA, Vaez JR, Pinheiro RR, Cavalcante ACR, Vitor RWA, Ahid SMM (2013) Seroprevalence and factors associated with Toxoplasma gondii infection in goats from rural properties in the municipality of Mossoró, RN. Pesq Vet Bras 33(5):565-570

30. Pereira MF, Peixoto RM, Langoni H, Greca Junior H, Azevedo SS, Porto WJN, Medeiros ES, Mota RA (2012) Risk factors associated with Toxoplasma gondii infection in sheep and goats in the state of Pernambuco. Pesq Vet Bras 32:140-146

31. Pinheiro RR, Gouveia AMG, Alves FSF, Haddad JPA (2000) Aspectos epidemioógicos da caprinocultura cearense. Arq Bras Med Vet Zootec 52(5):534-543

32. Santos KR, Lemos JF, Lopes CD, Sousa RA, Oliveira MRA, Luz CSM, Sousa Júnior SC (2018) Occurrence and risk factors for Toxoplasma gondii infection in goats from micro-regions of the state of Piauí. Semina Ci Agr 39:2457-2464

33. Tizard IR. Imunologia, Veterinária, $10^{\text {a }}$ ed., Rio de Janeiro: Elsevier, 2020

34. Unzaga JM, Moréa G, Bacigalupe D, Rambeaud M, Pardini L, Dellarupe A, De Felice L, Gos ML, Venturini MC (2014) Toxoplasma gondii and Neospora caninum infections in goat abortions from Argentina. Parasitol Int 63:865-867

35. Valencio BA, Bezerra R, Vilela VLR, Feitosa TF, Amaku M, Azevedo SS, Gennari SM (2020) Longitudinal study of Toxoplasma gondii antibodies in female lambs from Paraíba State, Brazil. Small Rum Res 188:106-125

36. Wanderley FS, Porto WJ, Câmara DR, Da Cruz NL, Feitosa BC, Freire RL, De Moraes EP, Mota RA (2013) Experimental vaginal infection of goats with semen contaminated with the "CPG" strain of Toxoplasma gondii. J Parasitol 99:610-613

37. Wang ZD, Liu HH, Ma ZX, Ma HY, Li ZY, Yang ZB, Zhu XQ, Xu B, Wei F, Liu Q (2017) Toxoplasma gondii infection in immunocompromised patients: a systematic review and Meta-Analysis. Front Microbiol 8(389):1-12

38. Zar JH (1999) Biostatistical analysis, fourth ed. Prentice Hall, Upper Saddle River

\section{Figures}




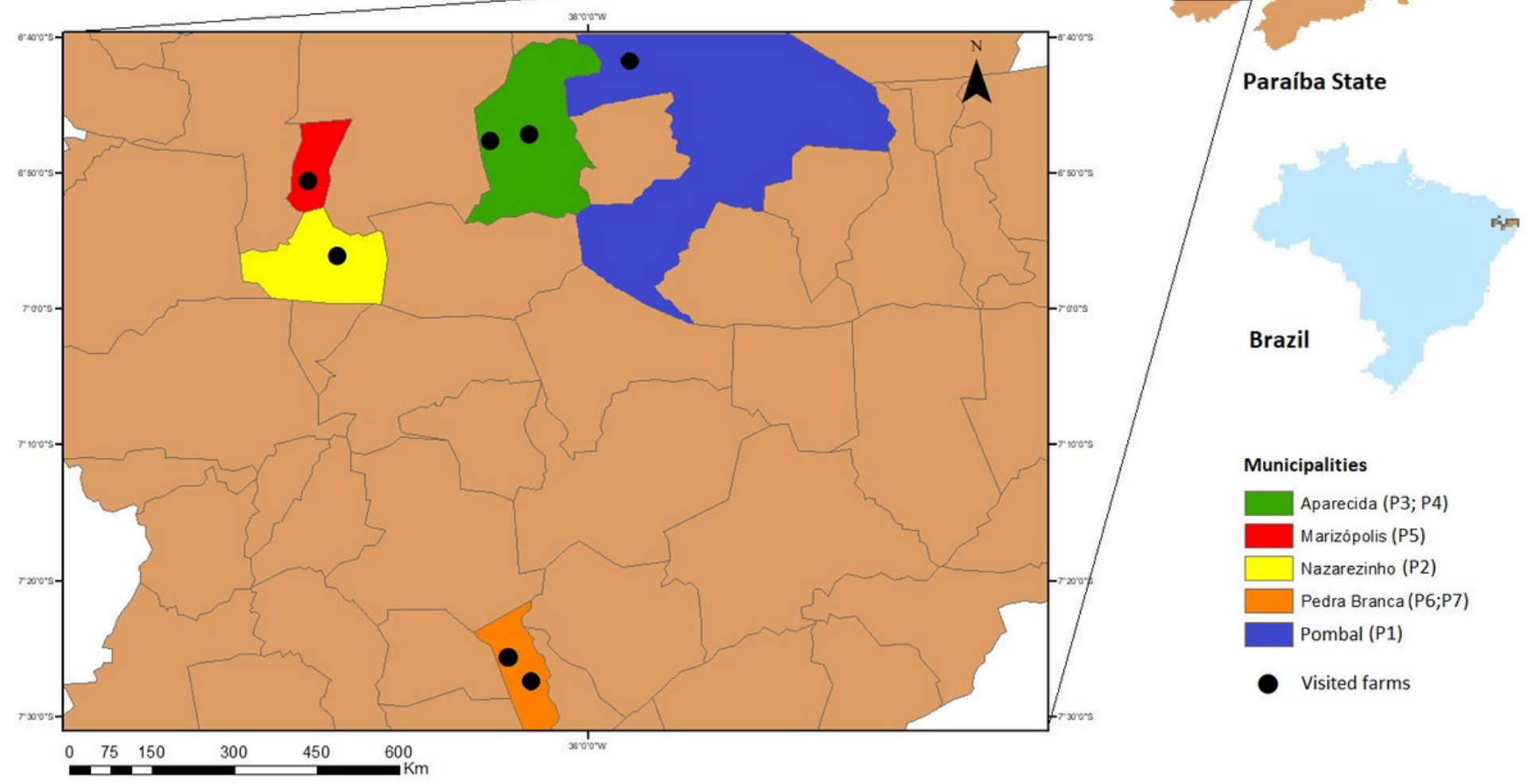

Figure 1

Geographical locations of the goat herds analyzed in the semiarid region of the state of Paraíba, northeastern Brazil. 

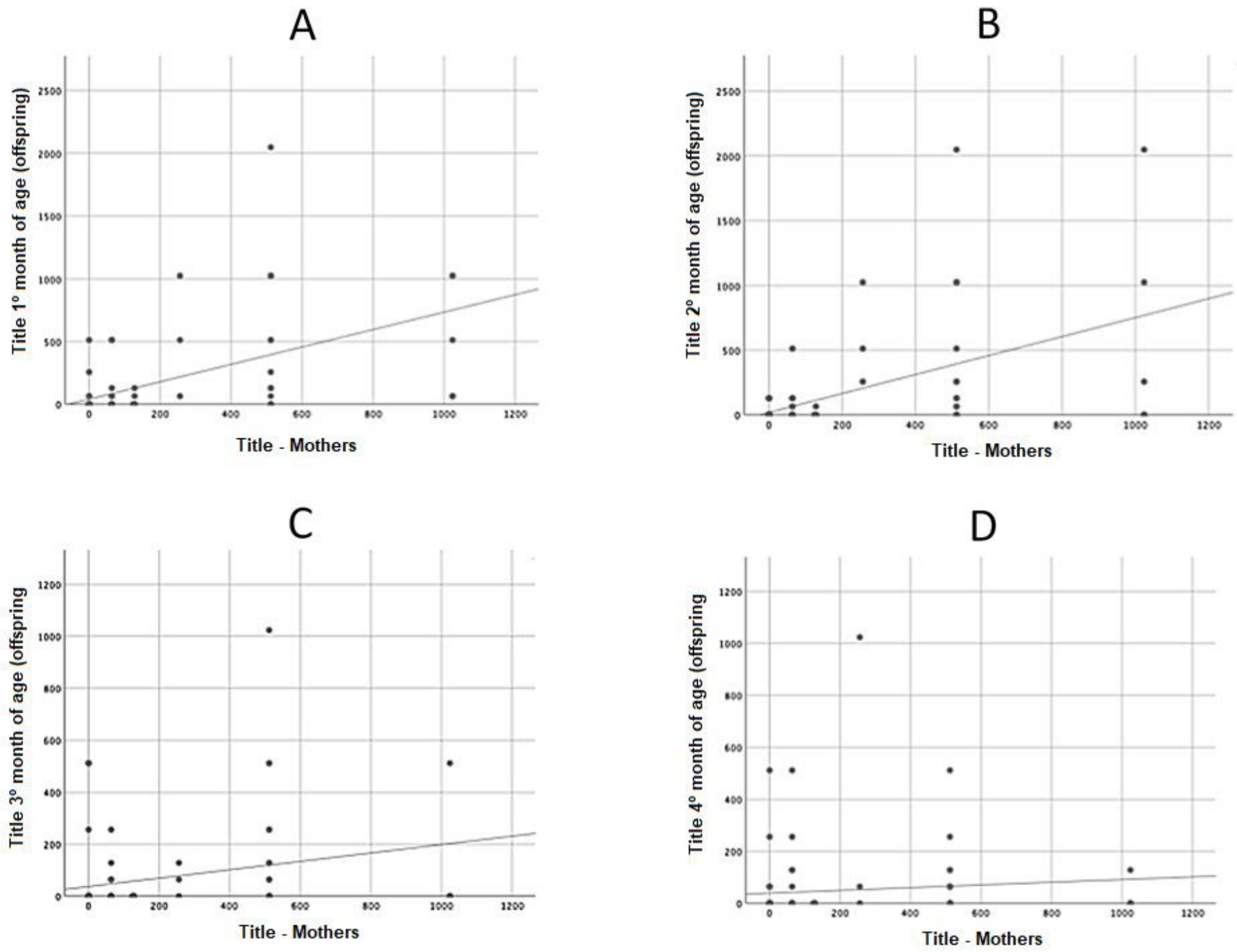

\section{Figure 2}

Scatter plots of the correlation analysis between the antibody titers of mothers $x$ offspring up to four months of age, demonstrating a significant correlation. A: First month $(R=0.645 ; p<0.0001) B$ : Second month $(R=0.592 ; p<0.0001 ; C$ third month $(R=0.359 ; p<0.0001)$; and $D$ : Fourth month $(R=0.289 ; p=0.005)$. 